\title{
Studying and Evaluating the Immune System in Urticaria, Asthma and Rhinitis
}

\author{
Ghanyia Jasim Shanyoor ${ }^{1}$, Rawaa Abdul-ameer Abdul-jabbar ${ }^{2}$, Ekhlass N. Ali ${ }^{1}$ \\ ${ }^{1}$ Ass. Prof., ${ }^{2}$ Lecturer, Biology Department, College of Science, Mustansiriyah University, Baghdad, Iraq
}

\begin{abstract}
Background: Diseases related with allergy such as urticaria, asthma, and rhinitis have an effect on autoimmune system.

Objectives: This study was planned and carried out to assess how the immunity affected in patients with allergy and urticaria, asthma, and rhinitis through measuring the total IgE and IL-33.

Materials and Method: A collection of females and males (74 patients) with urticaria, asthma, and rhinitis were chosen in this research, 24 with urticaria, 26 with asthma, and 24 with rhinitis their ages were ranged from 30 to 45 years while their weight ranged from 69 to $92 \mathrm{~kg}$, using immuno sorbent assay (ELISA), the IL-33 and IgE were calculated and evaluated respectively in the patients and the collected data were compared with healthy individuals (control).

Results: The data that was gathered from the blood serum of urticaria, asthma, and rhinitis patients indicates considerable differences in levels of IL-33 which were tolerated from 172 to $185 \mathrm{Ng} / \mathrm{l}$, while the IgE ranged from 321 to $397 \mathrm{Ng} / \mathrm{l}$ comparing with healthy individuals (control). Also results of specific IgE signify a existence for one or more inhalant allergens in urticaria, asthma, and rhinitis, especially in rhinitis patients, precisely in Weeds allergens (w6, w9), Tree allergens (t2, t3, t4, t7), and Grasse's allergens (g6, g12) and it was lower in females than males.

Conclusion: The considerable changes in the IL-33, and IgE in the patients affect the immunity system in the patients due to the chronic inflammatory diseases (urticaria, asthma, and rhinitis) and it will increased in patients with inhalant allergy.
\end{abstract}

Keywords: Urticaria, Asthma, Rhinitis, immunity, inhalant allergy.

\section{Introduction}

Allergens, which commonly are in urban communities as well as in modern societies, are certain materials or animals that cause a certain symptoms in respiratory system and in eyes; the signs may appears in lungs, noise, and eyes. It may also appear in the skin as eczema or red spots, and it affects the blood. Diseases

\section{Corresponding Author:}

Ghanyia Jasim Shanyoor

Ass. Prof., Biology Department, College of Science,

Mustansiriyah University, Baghdad, Iraq

e-mail:dr.alkarkhi@gmail.com, stkn@uomustansiriyah.edu.iq that appear due to allergens such as urticaria, asthma, and rhinitis may cause high sensitivity and disorder which affect the IL-33 and IgE percentages in blood and considered as pathogenic to allergic disease ${ }^{(1-3)}$.

IL-33 (Interleukin-33), associated with the molecular damage and is considered as immune system alert to allergens and usually considered as a IL-1 family member, thus it is an extracellular cytokine, therefore it is support endothelial cell against inflammation, and this enable the scientists and the researcher to consider it as a key factor to discover and characterize the diseases that related to allergy and this could be due to the activation of the immune cells (Th2) ${ }^{(4-6)}$.

$\operatorname{IgE}$ (immunoglobulin E) is a protein (antibody) by 
which the plasma cells are responsible to synthesize it and it is considered as allergy indicator in the body and used by the immune system in the duration of the defense against some syndrome ${ }^{(7,8)}$.

Recent studies assured the relationship and the link between allergy that caused by allergens substances and the level of $\operatorname{IgE}$ in the serum, this principle can be applied on urticaria, asthma, and rhinitis patients who suffered from these chronic diseases ${ }^{(9,10)}$.

The goal of the current study is to assess how the immunity affected in patients with allergy from certain materials and the patients who have urticaria, asthma, and rhinitis through examining the level of IgE and IL33 in blood serum.

\section{Materials and Method}

74 patients were chosen in this study, half of them were females while the other 37 were males, and they were classified according to their diseases ((24 Urticaria,
24 Rhinitis, and 26 Asthma). The sera were isolated from the blood samples, and were kept at $-70^{\circ} \mathrm{C}$. Healthy 28 individuals' half females and 14 were males, and they were included in the current study and used their sera for comparison with the 74 patients. Patients and healthy individuals were diagnosed by the special physicians in Allergic Specialized Center/Baghdad.

Immuno sorbent assay (ELISA), were carried out to indicate the levels of IL-33 and IgE and were calculated and evaluated respectively in the patients. The collected data were compared with healthy individuals (control).

Statistical analyses were also carried out using Minitab software for statistics, version 13. The P-value was also calculated using ANOVA.

\section{Result and Discussion}

Levels of IL-33 and IgE that appears from ELISA test were listed in table 1.

Table 1: Distribution of the studied groups according to (age, weight, specific IgE, and IL-33)

\begin{tabular}{|l|c|c|c|c|c|}
\hline Variable & $\begin{array}{c}\text { Patients with } \\
\text { Asthma Mean } \pm \text { SD }\end{array}$ & $\begin{array}{c}\text { Patients with } \\
\text { Urticaria Mean } \pm \text { SD }\end{array}$ & $\begin{array}{c}\text { Patients with } \\
\text { Rhinitis Mean } \pm \text { SD }\end{array}$ & $\begin{array}{c}\text { Control (28) } \\
\text { Mean } \pm \text { SD }\end{array}$ & P value \\
\hline Age & $31.20 \pm 7.28$ & $32.84 \pm 11.64$ & $30.19 \pm 12.17$ & $30.10 \pm 9.11$ & - \\
\hline Wight & $78.93 \pm 14.73$ & $74.15 \pm 9.78$ & $72.09 \pm 13.11$ & $70.03 \pm 15.89$ & - \\
\hline $\mathrm{IgE} \mathrm{Ng} / 1$ & $395.70 \pm 129.80$ & $319.90 \pm 136.58$ & $339.49 \pm 16.87$ & $37.87 \pm 27.61$ & 0.000 \\
\hline $\mathrm{IL}-33 \mathrm{Ng} / 1$ & $175.49 \pm 39.76$ & $173.69 \pm 40.01$ & $179.98 \pm 49.27$ & $115.58 \pm 14.11$ & 0.000 \\
\hline
\end{tabular}

From table 1 it was found that all the patients shows a significant increasing in the level of IgE comparing with control (healthy group), but patients with asthma have higher level of IgE than patients with urticaria, and rhinitis, the age and the weight of the patients doesn't shows and correlation with the level of IgE.

Table 2 represent the calculated data from inhalant allergies that caused by certain compounds to patients with allergy and urticaria, asthma, and rhinitis.

Results in table 2 indicate the correlation between the allergy that caused by inhalant and the three groups of patients (urticaria, asthma, and rhinitis), as towards animal, the results shows a high correlation between and the highest level $\operatorname{IgE}$ and the gender, females shows high inhalant allergy than males, while males affected with weed more than the females ${ }^{(11)}$.
Many studies confirm the correlation between the allergy toward animal and mite, precisely for urticaria patients, these studies indicates atopic allergies (dermal and respiratory) such as eczema, rhinitis and asthma ${ }^{(12,13)}$. Grass and tree allergies are higher in males than females, this conclusion was confirmed also by Cayrol and her team coworkers in $2014^{(14)}$, while for mold the females shows more inhalant allergy than males ${ }^{(11)}$.

Studies confirm the relationship between the level of IL-33 in patient serum and allergy, the data that were obtained in the current study (represented by table 1, and 2) shows a continuous changes in IL-33 structure due to the activation of many pathways signs as well as the inflammatory cells in asthma patients, this elevation depends on the typey of allergy, type of cellular damage and cellular stress production. 
Table 2: Estimation of serum level of specific IgE that caused by inhalant compounds

\begin{tabular}{|c|c|c|c|c|c|c|c|c|}
\hline \multirow{2}{*}{ Series } & \multirow{2}{*}{ Allergens } & \multirow{2}{*}{ Gender } & \multicolumn{2}{|c|}{ Urticaria } & \multicolumn{2}{|c|}{ Rhinitis } & \multicolumn{2}{|c|}{ Asthma } \\
\hline & & & No. & $\%$ & No. & $\%$ & No. & $\%$ \\
\hline \multirow{3}{*}{1} & \multirow{3}{*}{$\begin{array}{l}\text { Animal } \\
(\mathrm{e} 84, \mathrm{e} 82, \mathrm{e} 6, \mathrm{e} 5, \mathrm{e} 3, \mathrm{e} 2, \mathrm{e} 1)\end{array}$} & $\mathrm{F}$ & 2 & 8.30 & 5 & 20.80 & 4 & 15.40 \\
\hline & & M & 3 & 12.50 & 2 & 8.30 & 3 & 11.50 \\
\hline & & Total & 5 & 20.80 & 7 & 29.10 & 7 & 26.90 \\
\hline \multirow{3}{*}{2} & \multirow{3}{*}{$\begin{array}{l}\text { Weeds } \\
\text { (w9, w6) }\end{array}$} & $\mathrm{F}$ & 3 & 12.50 & 5 & 19.20 & 0 & 0.00 \\
\hline & & M & 6 & 25.00 & 5 & 19.20 & 0 & 0.00 \\
\hline & & Total & 9 & 37.50 & 10 & 38.40 & 0 & 0.00 \\
\hline \multirow{3}{*}{3} & \multirow{3}{*}{$\begin{array}{l}\text { Mite } \\
(\mathrm{d} 2, \mathrm{~d} 1)\end{array}$} & $\mathrm{F}$ & 5 & 20.80 & 3 & 11.50 & 3 & 12.50 \\
\hline & & M & 2 & 8.30 & 4 & 15.40 & 2 & 8.30 \\
\hline & & Total & 7 & 29.10 & 7 & 26.90 & 5 & 20.80 \\
\hline \multirow{3}{*}{4} & \multirow{3}{*}{$\begin{array}{l}\text { Tree } \\
(\mathrm{t} 7, \mathrm{t} 4, \mathrm{t} 3, \mathrm{t} 2)\end{array}$} & $\mathrm{F}$ & 5 & 20.8 & 10 & 38.50 & 2 & 8.30 \\
\hline & & M & 10 & 41.7 & 4 & 15.40 & 1 & 4.20 \\
\hline & & Total & 15 & 62.5 & 14 & 53.90 & 3 & 12.50 \\
\hline \multirow{3}{*}{5} & \multirow{3}{*}{$\begin{array}{l}\text { Grasses } \\
(\mathrm{g} 12, \mathrm{~g} 6)\end{array}$} & $\mathrm{F}$ & 4 & 15.40 & 7 & 26.90 & 0 & 0 \\
\hline & & M & 6 & 25.00 & 4 & 15.40 & 0 & 0 \\
\hline & & Total & 10 & 40.40 & 11 & 42.30 & 0 & 0 \\
\hline \multirow{3}{*}{6} & \multirow{3}{*}{$\begin{array}{l}\text { Mold } \\
(\mathrm{m} 6, \mathrm{~m} 3, \mathrm{~m} 2, \mathrm{~m} 1)\end{array}$} & $\mathrm{F}$ & 3 & 12.50 & 1 & 3.80 & 2 & 8.30 \\
\hline & & M & 0 & 0.00 & 1 & 3.80 & 0 & 0 \\
\hline & & Total & 3 & 12.90 & 2 & 7.60 & 2 & 8.30 \\
\hline
\end{tabular}

Source of Funding: Self fund.

Conflict of Interest: No conflict of interest

Ethic Statement: The researchers already have ethical clearance from all required institution and laboratories.

\section{References}

1. Franzese C. Diagnosis of Inhalant Allergies: Patient history and Testing. Otolaryngologic Clinics of North America. 2011; 44(3): 611-623. https://doi. org/10.1016/j.otc.2011.03.003

2. Smith DE. IL-33 meets allergens at the gate. Nature Immunology. 2018; 19(4):318-320

3. Ding W, Zou GL, Zhang W, Lai XN, Chen HW, Xiong LX. Interleukin-33: Its Emerging Role in Allergic Diseases. Molecules. 2018; 23(7): 1665. doi: 10.3390/molecules23071665

4. Martin N.T., Martin M.U. Interleukin 33 is a guardian of barriers and a local alarmin. Nature Immunology. 2016; 17: 122-131. doi: 10.1038/ ni.3370.
5. Cayrol C., Duval A., Schmitt P., Roga S., Camus M., Stella A., Burlet-Schiltz O., Gonzalez-dePeredo A., Girard J.P. Environmental allergens induce allergic inflammation through proteolytic maturation of IL-33. Nature Immunology. 2018; 19: 375-385. doi: 10.1038/s41590-018-0067-5.

6. Cayrol C., Duval A., Schmitt P., Roga S., Camus M., Stella A., Burlet-Schiltz O., Gonzalez-dePeredo A., Girard J.P. Environmental allergens induce allergic inflammation through proteolytic maturation of IL-33. Nature Immunology. 2018; 19: 375-385.

7. Platts-Mills TAE, Schuyler AJ, Erwin EA, Commins SP, Woodfolk JA. IgE in the diagnosis and treatment of allergic disease. Journal of Allergy and Clinical Immunology. 2016; 137(6): 16621670. doi: 10.1016/j.jaci.2016.04.010.

8. Wilson JM, Nguyen AT, Schuyler AJ, Commins SP, Taylor AM, Platts-Mills TAE, McNamara CA. IgE to the Mammalian Oligosaccharide Galactose$\alpha-1,3$-Galactose Is Associated With Increased Atheroma Volume and Plaques With Unstable 
Characteristics-Brief Report. Arteriosclerosis, Thrombosis, and Vascular Biology. 2018; 38(7): 1665-1669. doi: 10.1161/ATVBAHA.118.311222.

9. Kounis NG, Hahalis G. Serum IgE levels in coronary artery disease. Atherosclerosis. 2016; 251: 498500. doi: 10.1016/j.atherosclerosis.2016.05.045.

10. Commins SP, Jerath MR, Cox K, Erickson LD, Platts-Mills T. Delayed anaphylaxis to alpha-gal, an oligosaccharide in mammalian meat. Allergology International. 2016; 65: 16-20. doi: 10.1016/j. alit.2015.10.001.

11. Ferastraoaru D, Bax HJ, Bergmann C, Capron M, Castells M, Dombrowicz D, et al. AllergoOncology: ultra-low IgE, a potential novel biomarker in cancer-a Position Paper of the European Academy of Allergy and Clinical Immunology (EAACI).
Clinical Translation Allergy. . 2020; 10: 32. doi: 10.1186/s13601-020-00335-w.

12. Caliskaner Z, Ozturk S, Turan M, Karaayvaz M. Skin test positivity to aeroallergens in the patients with chronic urticaria without allergic respiratory disease. Journal of Investigation in Allergology Clinical Immunology. 2004; 14(1): 50-54.

13. Mahesh P A, Kushalappa P A, Holla AD, Vedanthan PK. House dust mite sensitivity is a factor in chronic urticaria. Indian Journal of Dermatology Venereology and Leprology. 2005; 71(2): 99-101.

14. Cayrol C., Girard J.P. IL-33: An alarmin cytokine with crucial roles in innate immunity, inflammation and allergy. Current Opinion in Immunology. 2014; 31: $31-37$. 